\title{
Teaching and Research in Urban Geography at the University of Lausanne A model at the beginning of a new century
}

\author{
Antonio Da Cunha, Jean-Bernard Racine, Lausanne
}

\section{Introduction: the context}

Teaching and research in urban geography at the Institute of Geography, Lausanne, has been structured in two distinct phases and focuses on two approaches: on the one hand on the model of the city in space, and on the other hand on the model of the city as space, according to BRIAN J.L. BERRY's famous expression (1964) «cities as systems within a system of cities». Thus, the focus on the dynamic study of the general characteristics of the object «town» in an urban system of dissymetric interdependencies at a regional, national or global scale (Pumain 1997) was followed by the study of cities as physiognomic and socio-economic entities. This is differentiated through frameworks that are morphological, structure-functional and socio-cultural, with the emphasis on the study of urban landscapes. In other words, «cities amongst networks and territories» (SAINT-JULIEN 2002).

Writing about important urban problems is inevitably accompanied by new words. Sustainability has recently entered the geographic vocabulary. It can be presented as a descriptive concept, as a project and as a notion that aims at the implementation of innovating information and regulation systems. These have to do with all aspects of the decision process in urban communities. The fact that research perspectives have changed since the emergence of the environmental question, does not however imply that social, cultural and political dimensions are being ignored. The aim of both teaching and research at the Institute of Geography, Lausanne, remains and will remain anthropocentric: the human being is both the actor and the main concern of sustainable development.

Lectures are offered in two main lines of study that are nevertheless considered complementary. In the one line of study, the Institute offers a course on urban sustainable development and the contribution of cities to ecological and social sustainability, to be followed by a course on public politics and two specialised courses focusing on questions of transport and mobility, and on the topic of urban social cohesion. In essence, these courses encourage students to question the course of current developments and to collectively invent possible «futures» in a context of uncertainty (DA CUNHA \&
RACINE 2000). In the other line of study and research, the focus is on the relationship between cities, societies and culture from a more humanistic and phenomenological perspective (RACINE 1993). Not only does this perspective affect our political attitudes, but it also affects our projects, our values, our imagination, our socio-affective and emotional relationships with the city through our mental representations (Bochet \& RACINE 2002) - in other words, everything that contributes towards forming the dominant ideology of a society.

\section{Cities and sustainable development}

The research directions of sustainable urban development at the Institute of Geography involve at least three complementary concepts of the urban phenomenon «city»: the city as a social and physical system; the city as a structure and as a product of the actions and representations of the actors; the city as a living and activity space. As a social product and a place of economic and symbolic accumulation, the city is an uncertain and constantly changing space, which can be represented as a system in which cultural, economic, political and physical factors interact. The city is the expression of the social and technological division of work. It produces neither the necessary raw material nor the energy to satisfy all the needs and demands of its population. It is thus an open system. On the one hand its metabolism must constantly feed from external flows drawn from a nearby or distant environment. On the other hand, after processing and transforming these resources, the city ejects part of its waste into the surrounding environment. It can therefore transfer its entropic flows into a more or less wide environment (Fig. 1).

The quality of the buildings and the habitat is the signature of the city and is one of the fundamental elements influencing resident's quality of life. It is also a constructed environment, a place of life made of buildings and structures, made to last or to be transient, in close proximity and serviced by diversified technological networks. The connectivity and the quality of the urban network insure the resident's physical access to the diversified commodities and functions that the city offers simultaneously. We can therefore rightfully represent the city as an open system structured by three systems of activity: economic, cultural and political. These can be subdivided into one or more basic func- 


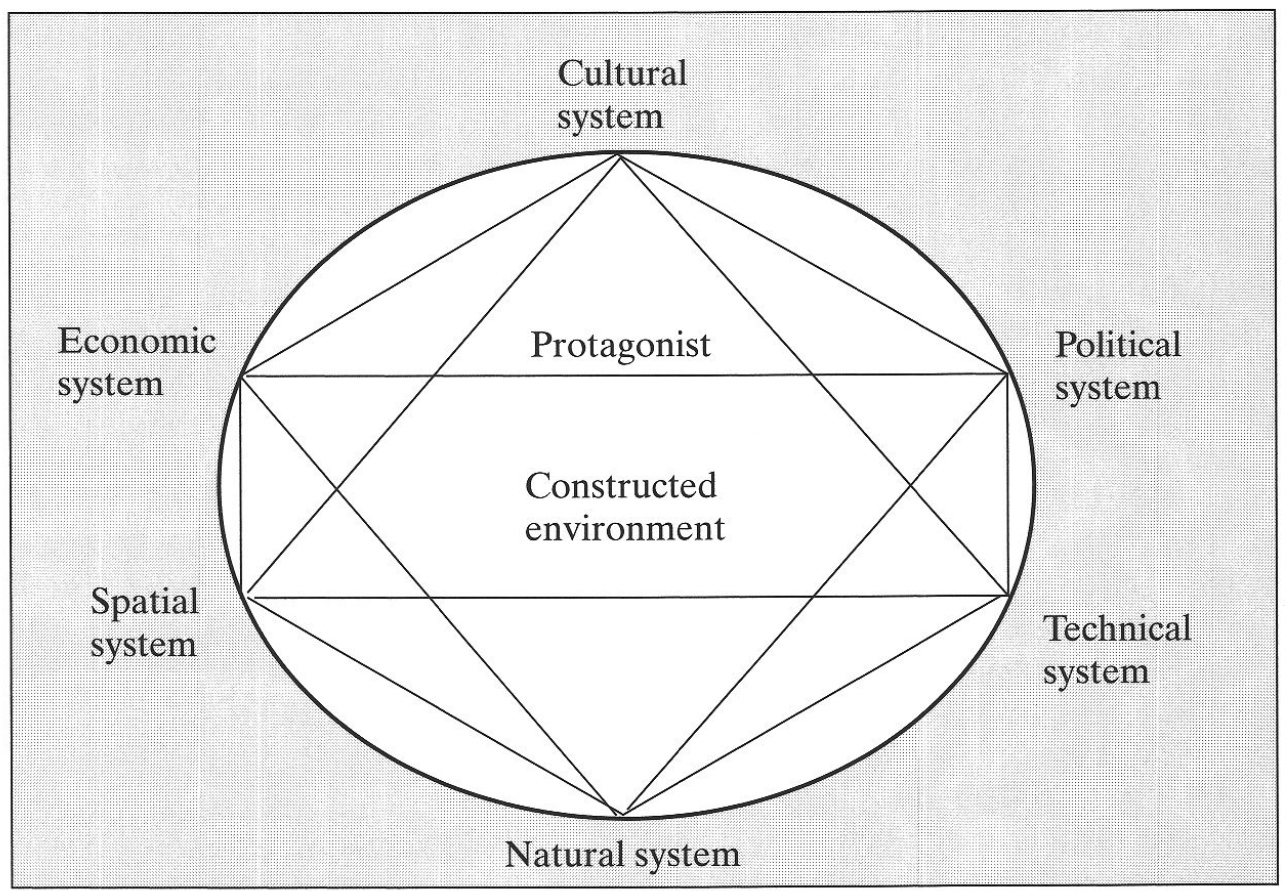

Fig. 1: The city is a system, open, complex and uncertain.

Die Stadt ist ein System, offen, komplex und mit Unsicherheiten behaftet.

La ville est un système, ouvert, complexe et incertain.

Draft: A. DA CunHA

tions of social reproduction. The identification of the device that permits economic, cultural and political functions, places the cities, urban agglomerations and metropolises in a hierarchy of urban centralities or further, in a hierarchy of potential developments. Urban change thus appears to be the result of collective actions that organise, transform and plan the basic structures of the city. The problems that the urban actors have to deal with are multiple and imply varied modes of action.

Action must be based on the «precaution principle», a rule according to which the decisions and measures chosen must favour caution whenever major social or ecological damage is possible, but the knowledge is incomplete. Even though our concept of urban systems has proved to be inadequate, the modes of production need to be challenged. The current situation in industrial ecology is evidence that changes in production modes are not only necessary, but also possible. The choice of production techniques affects the resources involved (renewable, non-renewable, recyclable, non-recyclable, critical, vulnerable, etc.) as well as the type of profession and the organisation of work. Do technological changes that are made in an effort to preserve the environment allow us to reach the same or a better level of services with a smaller quantity of raw material and energy? Moreover, can dispersed or concentrated habitat, the zoning of economic activities or social differentiation of space, or the manner in which people and activities locate themselves have important social and economic implications? The joint organisation of space and transport systems, at local regional or national levels, appears to be a major harmonisation factor. One of the major issues in current geography research is the different ways of changing the collective models of spatial mobility by investigating the impact of urban density, the use of resources and the resident's quality of life (BocheT \& PINI 2002).

We are familiar with the diagnosis linked to the current trend in the new urbanisation regime that established itself over the last thirty years (Da CunHA \& SCHULLER 2001). It is characterised by the transformation of the spatial relation between the «urban core» of an agglomeration and the suburban and periurban zones. This implies the creation of urbanised areas that are increasingly wide-spread, heterogeneous and fragmented, and that generate not only at an even larger scale the movement of people, but also of capital transfers, as well as information and service flux. The «new urban issue» emphasises the ambiguity of the current modalities of city-development, and the need to con- 
trol the physical effects (spatial disconnection, discontinuities, ruptures in residential quality), the economic effects (functional specialisation, zoning), the social effects (residential segregation, community withdrawal), the environmental effects (pollution, noise and nuisance factors), but also the political effects (dispersion and abundance of actors of urban management and regulation). In response to this development, teaching and research at the Institute of Geography of the University of Lausanne has based its activities on sustainable urban development around the following ten theses (Da Cunha \& Bochet 2002):

1. The city is a transformational reality: the urban environment is a collective patrimony, a place of symbolic and material accumulation.

2. The city is a translocal reality: the order of the city implies the disorder of its spatial surrounds.

3. Cities are imperfect artificial ecosystems: the valorisation of patrimony and the control over urban fluxes is insufficient.

4. Cities are not sustainable, but can contribute to sustainability.

5. A compact city can favour sustainability: extensive urbanisation is ineffective from the point of view of the use of collective resources.

6. The organisation of urban space is a harmonisation factor for economic, social and ecological aims in sustainable development.

7. The quality of public places and the distribution of collective equipment is a symbolic expression of the territorial relationship on the scale of agglomerations: each place is concurrently an integral part of the agglomeration and a part of urban centrality.

8. Cities must assimilate management principles similar to those that govern natural systems such as the management of resources.

9. The urban development policy is an essential tool for the reflection on the future development of the city.

10. Sustainable public actions must involve new modes of intervention essential to the practice of a collective apprenticeship that guarantees good urban opening.

Each of these theses constitute a research agenda in themselves (Fig. 2).

A further focus of sustainable urban development at the Institute has for several years been urban vulnerability in connection with violence (NOSEDA 2001; RACINE 2002b). In this area, special attention should be paid by both theory and practice (e.g. public authorities) to incivility and feelings of insecurity as multifactor phenomena. Recently, the Institute has also included the role of the tertiary sector in the city and urban economic interdependancy into its research programme (MARENGo \& RACINE 2003). Both of the above research topics are considered to be unavoidable dimensions of social sustainability, and are for this reason included in Lausanne's Agenda 21. Likewise, the problems of social and anomic polarisation (danger, poverty, violence, social and cultural fragmentation, loneliness, consumerism, individualism) are characteristic of cities and have a tendency to disintegrate social bonds and to produce spatial segregation within the city (e.g. periurban territories) (Da CunHA, LERESCHE \& VEZ 1998). Harmonising the evolution of the common economic, social, cultural and physical spheres in a way that satisfies the needs of the present and future generations has become a major issue in urban research and activity.

\section{Cities, societies and cultures}

By acknowledging cities as places of memory and culture, as social fields charged with history, teaching and research at the Institute of Geography award similar importance to the relationship between cities and urban cultures, taking into account the duality of the relationship - culture forming cities and cities forming specific cultures. Even at the simple morphological level, the study of the evolution of urban plans and structures today takes architectural aspects into consideration. Harvey (1989) sees post-modernism as the ideological parallel to the rise of flexible capitalism. By valuing the return to the source of the architectural domain, this line of research plays on forms by the collage of different styles which become a collage of styles of life, consumption and new production relationships, responsible for the revitalisation of waterfronts and of mixed and integrated development where eclecticism is dominant. Thus, the above appears to form a natural counterweight to the fragmentation, the multinodality, the fluidity, the plurality and the hierarchy of cities. But what is architectural post-modernism and its proliferation of signs? It appears to replace history by reference and usage by symbols. However, it is not by adding new façades to subsidised housing that one can resolve the problems of large housing estates; neither by re-designing the layout of paved areas that one can create centres. It would seem that the valorization and treatment of the urban past and of «places of collective memory» have become tools of urban promotion. One could even say that selected parts of towns are themselves treated like sculptures, «pieces of culture», theatre decor and monuments rather than according to authentic terms of habitat - the buildings themselves being conceived as manifestations of the urban dimension. The significance of space has replaced its needs of space.

By highlighting the process of «going» from «having» 


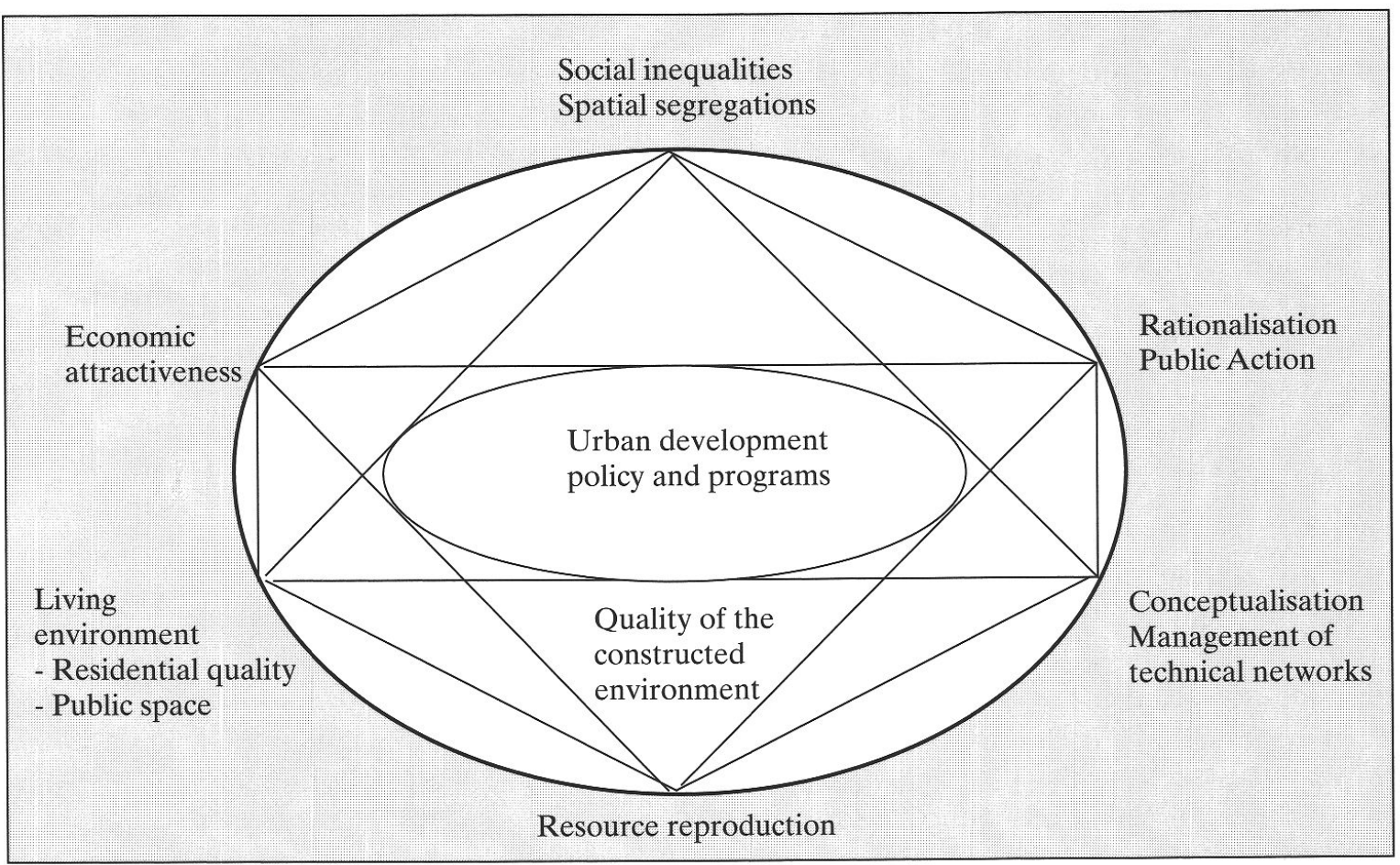

Fig. 2: The issues of durable urban development change during the process of change; they rationalise public action, harmonize economic change, social development and the renewal of natural resources.

Der Ausdruck dauerhafter Stadtentwicklung ändert sich im Prozess des Wandels, begründet öffentliches Handeln, harmonisiert ökonomischen Wandel, soziale Entwicklung und die Erneuerung natürlicher Ressourcen.

Les enjeux du changement dans le processus du développement urbain durable rationalisent l'action publique, harmonisent le changement économique, le développement social et la reproduction des ressources naturelles. Draft: A. DA CunHA

to «looking like» after having experienced the passage from «being» to «having», SöDERSTRÖM (1990) reminds us that

«cities undergo transformations that go more in the direction of a more intensive economic exploitation of space and an ever-increasing spectacular appearance to urban operations».

Are these an expression of the «prestige game» and subtle competition between specialists, between cities, who are all trying to give themselves both a face and an image - a brand image which upholds their own idea of urban living? These are the really ambiguous problems city marketing is confronted with.

Obviously, culture and economy are not antagonistic (Da CunHa 1989; RACINE 1989), and even if culture, as a form of shared experience, often appears free and non-marketable, it is still part of two undividable realities. As cities offer entertainment, publications, cultural clubs, exhibitions, and cinemas, they are partly in a position to polarise and to transform regional environments. Thus, large metropolises and small towns compete in the areas of art and culture. The trend in cultural investment today is to address increasingly qualitative needs of the urban and suburban population, while producing added value and geographic externalities which are profitable to consumers and businesses alike.

This emphasis on the relations between cities and culture can take different forms. One of the fundamental questions that we ask and will continue asking, from the point of view of the complex mosaic of social intraurban and metropolitan environments, is in the words of Touraine (1997): «How can we live together, equal and different?». For geographers, the focus is on the impacting of space, i.e. the role of space and the links to individuals searching for their place therein. A special emphasis is put on heterogeneity and pluralism, which we consider, along with the idea of urban ecosystems, as basic principles of urbanity, as universal characteristics of cities. This placing of value upon heterogeneity is today a driving-force in the transformation and rehabilitation of urban environments. Changes are occurring and the cultural minorities are the privileged actors of this change. JAGGI (2002), one 
of Lausanne's former mayors, who lectures on «The urban condition» at the Institute, recently said, in connection with urban cultural minorities:

«they often express themselves in an unstable and changeable manner. They are eminently contemporary. They evolve like tribal cultures, global as well as partial, permanent and temporary. The geography of these cultures escapes all kinds of confinement. They take-over and occupy industrial and commercial premises, which were not initially intended for them. They take advantage of urban derelict land. They destroy pre-established functions by using urban equipments in unexpected and spontaneous manners».

Further, the Institute focuses on both the change in cultural geography and its ambition to surpass the assumptions made by a geography of perception and representations, thus aiming at «unmasking the city» by discovering its symbolic meanings. The goal is to see cities not just a collection of material artefacts, but as places through which ideologies are projected and through which cultural values are expressed and power is excercised, where symbolic meanings of landscapes and buildings can be established by builders, architects, constructors, planners or owners, but that these actors themselves are influenced by dominating concepts of culture and class. The greatest difficulty in this line of research is that the change in the symbolic meanings of space occurs at the same time as the societies that surround them evolve (Harvey 2000). The social evolution can be rapid during a revolution, or gradual and influences the symbolic meaning of landscapes. Of interest is the way people interpret it, react to it, or absorb these significations and ideologies that are inscribed in the city. Is there really a link between the meanings that are inscribed in the urban landscapes and those that are perceived by people who come across these same landscapes? Obviously, the meanings that people put on these urban landscapes are much more diverse and complex than scientists of semiotics have made us believe.

By taking into account these basic principles, from the phenomenological and actionalist point of views dear to Giddens (1984) and his «double hermeneutics» to the acknowledgement of the key-role of «competent actors», our field research and courses allow room for ethno-methodological techniques widely used and implemented in Lausanne (MARENGO \& RACINE 1998; RACINE \& MAGer 1999; MARENGo 2002; RACINE 2002a) within the context of the Institute's participation in the NRP 39 (National Research Programme) of the SNRF (Swiss National Research Fund). The programme with the title «Migrations and intercultural relations», and the generic title «Places of interculturality» looks at how foreign and native social actors manage to classify their relationship to the environ- ment and the society in which they live. We no longer want a description of places that depends only on the disembodied knowledge of the researchers, but rather a descriptive activity from the actors. MonDADA (2000) reminds us that an actor's/agent's social activity cannot be separated from the acts of description, interpretation and symbolic elaboration that define them, giving them a meaning while taking them into account. Classification procedures are part of these activities. Not only do they allow the actors to identify known or unknown people, but also to interpret the activities, positions, options, frequentations that are part of the categories. The welcome opportunity to conduct an analysis that includes the actors' real-life experiences and representations has been conducted at several levels: the city's space, the relational space of associations, and the private space of actors, which covers, creates and gives sense to these various spaces. In view of the results obtained, we remain convinced that in order to be fully meaningful and useful for action, ethno-methodology, as we have practised, must be accompanied by reflections on the objective structure of the relationships between actors (individual, collective, institutional) and by the respective positioning of these actors in the social environment. Individual perceptions and categories of interpretation that actors apply to reality come partially from this same objective structure.

\section{Conclusions and perspectives}

The concept of socially sustainable development gives us the opportunity to «re-read» a large variety of urban subjects from a new perspective. It leads us to reflect on the economic changes in cities, on their social and cultural development as well as on the conditions for a cautious development in terms of ecological conservation. Further, this sustainability concept also leads us to discover new methods of urban management. Designed as a governing system capable of linking up political institutions, social actors and private organisations in a process of elaboration and implementation of collective decisions, the search for an «urban governance» method can also be considered as the search for a planning and urban action technique. It expresses the need and intentions to collectively build a true «urban development policy» that depends on the active participation of city dwellers. Thus, this concept merits being put to the test as a fundamental social issue.

The students are encouraged to consider distinct spatial and temporal scales of analysis when investigating the different links between economic, social and ecological processes. They are also encouraged to overcome the dichotomy between knowledge and know- 
how and between research and action by observing the different dimensions of change in urban societies. And finally they are warned to be careful not to prevent democratic debate by favouring a simple exercise of methods of investigation. It is obvious that the management of cities and territories will profit from a better understanding of the interactions mentioned above. Their study calls for the use of distinct disciplines and lines of questions.

It is clear: in our opinion, urban problems do not have disciplinary boundaries. Our scientific research focuses on the Swiss urban and territorial development. In comparison to other countries, Switzerland already has a clear background in reflective and critical evaluation, which enables suitable investigation into the quality of governance in economic, social and ecological areas and in the practices of public life. In echo or in essential contrast, we also use our heritage and our experience of North American, and in particular of Canadian cities. Recently, we have incorporated research on new African cities.

Cities constitute specific innovative environments that play a pioneer part in innovative processes. Thus cities must necessarily produce innovation in order to find solutions to the new problems they face - from within the city, as well as from their relation to surrounding territories - which would imply that cities are environments that naturally favour innovation in terms of governance and management of economic changes, and of socio-cultural diversity and differences, as well as habitat production. Initiating a reflection on the «new urban issue», on the changes in cities, their issues and their implications for research and action, is the primary target of our teaching and research.

\section{References}

BERRY, B.J.L. (1964): Cities as systems within systems of cities. - Papers and proceedings of the regional science Association, vol. 13: 147-164.

Bochet, B. \& G. PINI (2002): Formes urbaines et mobilité: quelles stratégies pour un développement durable? - Vues sur la ville 4: 3-5, Institut de Géographie, Université de Lausanne.

Bochet, B. \& J.-B. Racine (2002): Connaître et penser la ville: plaidoyer pour l'exploration des affects et des émotions dans la géographie urbaine. - GéoCarrefour, Lyon 77, 2:117-132.

Da Cunha, A. (1989): Culture et économie; la ville de Lausanne. - Ville de Lausanne: Office d'études socioéconomiques et statistiques.

Da Cunha, A. \& B. Bochet (2002): Développement urbain Durable. - In: Vues sur la ville 1:3-5, Institut de Géographie, Université de Lausanne.

Da Cunha, A., Leresche, J.PH. \& I. VeZ (1998): Pauvreté urbaine, le lien et les lieux. - Lausanne: Réalités sociales.
Da Cunha, A. \& J.-B. Racine (2000): Sustainable Development, the Quality of the Urban Environment and Governance; Issues in Urban Research, or How to Change the Process of Change. - In: Ianos, I., Pumain, D. \& J.-B. Racine: Integreted Urban Systems and Sustainability of Urban Life. - Bucarest: Editura Tehnicà, S.A.: 77-110.

Da Cunha, A. \& M. Schuller (2001): Métropolisation, changement de régime d'urbanisation et fragmentation de l'espace: enjeux de la gouvernance des agglomérations en Suisse. - Revue suisse de science politique 7, 4: 119-126.

GiDDENS,A.(1984):The constitution of society: outline of the theory of structuration. - Cambridge: Polity Press.

Harvey, D. (1989): The Condition of Postmodernity. Oxford: Blackwell.

Harvey, D. (2000): Spaces of Hope. - Berkeley, Los Angeles: University of California Press.

JAGGI, Y. (2002): Villes et cultures. - In: RACINE, J.B. \& Y. JAGGI: Villes et cultures. - Vues sur la ville 5: 3-5, Institut de Géographie, Université de Lausanne.

Marengo, M. (2002): Interculturality: A Preferential Path in the Search for a New Urban Social Equilibrium. - In: SchNeLL, I. \& W. OstendoRf (eds): Studies in Segregation and Desegregation. - Aldershot: Ashgate Publishing Ltd: 87-106.

Marengo, M. \& J.-B. Racine (1998): Migrations et relations interculturelles: les lieux de l'interculturalité. - In: Géographie et Cultures 25: 22-37.

Marengo, M. \& J.B. Racine (2003): Des villes pour vivre durablement ensemble: le tiers secteur et l'économie solidaire à Lausanne. - Rapport pour l'Agenda 21, Ville de Lausanne/Institut de Géographie de l'Université de Lausanne (in press).

Mondada, L. (2000): Décrire la ville. - Paris, Anthropos, collection Villes.

NosedA, V. (2001): Les sauvageons et les statistiques. Le problème de classement dans l'interprétation des statistiques sur la délinquance et les violences urbaines. - Besançon: Téoquant.

Pumain, D. (1997): Pour une théorie évolutive des villes. - In: L'Espace géographique 26, 2: 119-134.

RACINE, J.-B. (1989): Villes et dynamiques culturelles. - In: Bourquin, J.F. (éd.): Le pacte du Futur, Culture, Economie, Communication: Les nouveaux réseaux d'échange et de solidarité. - Genève: Zoé: 44-53.

RACINE, J.-B. (1993): La ville entre Dieu et les hommes. - Paris: Anthropos, Genève: Presses bibliques universitaires.

Racine, J.-B. (2002a): Migration, Places and Intercultural Relations in Cities. - In: SCHNELL, I. \& W. OSTENDORF (eds): Studies in Segregation and Desegregation. - Aldershot: Ashgate Publishing Ltd: 67-86.

RACINE, J.-B. (2002b): Explaining, regulating or monitoring violence in the cities of tomorrow. Appraisals from French and Swiss experience. - In: DAVIES, W.S. \& I.J. Townshend (eds): Monitoring Cities: International 
Perspectives. - IGI Commission Monitoring Cities for Tomorrow, University of Calgary Press and Freie Universität Berlin: 557-597.

Racine, J.-B. \& CH. Mager (1999): The foreigner and the city: from co-presence to interaction. In search of intercultural places in Lausanne. - In: Aguilar, A. \& I. Escamilla (eds): Problems of Megacities: Social Inequalities, Environmental Risk and Urban Governance. - Universidad National Autonoma de México, UNAM, Commission of Urban Development and Urban Life, IGU: 477-498.

Saint-Julien, Th. (2002): Les villes entre réseaux et territoires. - In: Charvet, J.P. \& M. Sivignon (éd.): Géographie humaine, questions et enjeux du monde contemporain. - Paris: A. Colin: 151-188.

SöDERSTRÖM, O. (1990): Spectacle, dérive et détournement. - Etudes de Lettres 1, Université de Lausanne.

Touraine, A. (1997): Pourrons-nous vivre ensemble. Egaux et différents. - Paris: Fayard.

\section{Further readings}

Bassand, M., Da Cunha, A. \& J. Tarradellas (2000): Métropole et métropolitain. - In: BAsSAND, M. et al.: Métropolisation, crise écologique et développement durable. L'eau, l'habitat précaire à Ho Chi Minh-Ville, Vietnam. - Lausanne: Presses polytechniques et universitaires romandes: 79-95.

Chalas, Y. (2000): L'invention de la ville. - Paris: Anthropos, Economica, Collection Villes.

ChoAy, F. \& P. Merlin (1988): Dictionnaire de l'urbanisme et de l'aménagement. - Paris: PUF.

ChOAY, F. (1994): Le règne de l'urbain et la mort de la ville. La ville, art et architecture en Europe, 1870-1993. - Paris: Centre Georges-Pompidou.

Da Cunha, A. (1996): Métropolisation, processus d'exclusion et développement durable: question urbaine. In: JACCOUD, CH. et al. (éd.): Raison et déraisons de la ville, approches du champ urbain. - Lausanne, Presses polytechniques et universitaires romandes: 21-44.
Portzamparc, Ch. De (1995): Préface. - In: Mongin, O.: Vers la troisième ville? - Paris: Hachette.

Panerai, Ph., Castex, J. \& J.P. Depaule (2001): Formes urbaines de l'îlot à la barre. - Marseille: Parenthèse.

RACINE, J.-B. (1990): Villes et géographie urbaine pour les années 90: une problématique en mutation. - In: Etudes de Lettres, Université de Lausanne: 27-46.

Racine, J.-B. (1994): Entre Chaman et Méphisto: les villes ont-elles une âme? Quelques réflexions sur la recherche et l'exploitation des identités urbaines. - In: BASSAND, M. \& J.P. LeREsche (éd.): Les Faces cachées de l'urbain. - Berne: Peter Lang: 43-59.

REMY, J. \& L. Voyé (1992): La ville: vers une nouvelle définition? - Paris, L'Harmattan.

Remy, J. (1993): La morphologie de l'habitat comme ressource sociale. - In: Revue des sciences sociales de la France de l'Est: 166-176.

SöDERSTRÖM, O. (1996): Les métamorphoses du patrimoine, formes et conservation du construit et urbanité. - Faculté des lettres, thèse de doctorat, Université de Lausanne.

Prof. Dr. Antonio Da Cunha, Prof. Dr. Jean-Bernard Racine, Institut de Géographie de l'Université de Lausanne, Bâtiment des Facultés des Sciences Humaines II, CH-1015 Lausanne/Dorigny.

\section{Internet address}

Institut de Géographie de l'Université de Lausanne: http://www.unil.ch/igul/ 